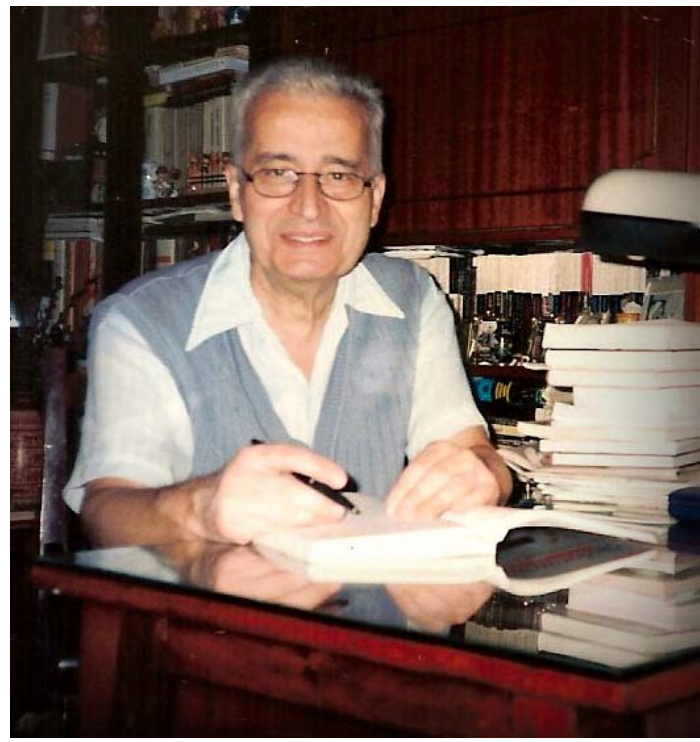

\title{
In memoriam Professor Ioan Matei
} (1939-2017)

On August $23^{\text {rd }}$ 2017, an exceptional, accomplished man, Professor Ioan Matei (Puiu, to his close fellows), passed away with the same discretion that characterized his life amongst us. Professor Ioan Matei was one of the most prominent representatives of the School of Internal Medicine at the "Colentina" Clinical Hospital in Bucharest, which was founded by Acad. Nicolae Gh. Lupu and later developed by Acad. Professor Ioan Emil Bruckner and Professor Simion Purice.

He was born in Piteşti on April $19^{\text {th }} 1939$ to a family of intellectuals (his father had been a highly appreciated teacher of history at the "Nicolae Bălcescu" Secondary School in Piteşti for several decades). He graduated from the former "Nicolae Bălcescu" Secondary School (presently known as "Ion C. Brătianu" National College) in 1956 and then attended the Faculty of Medicine at the "Carol Davila" University of Medicine and Pharmacy in Bucharest. He graduated as valedictorian in 1962.

He began his academic career at "Carol Davila" University of Medicine and Pharmacy as a teaching assistant (1965), proceeding as an assistant (1968), lecturer (1974), Associate Professor (1990) and Professor (1993). He was the Head of the Department of Internal Medicine at the "Colentina" Clinical Hospital for ten years, from 1994 till 2004. After completing his internship he became a specialist physician (1969), then a primary care physician in Internal Medicine (1973). He was also the Head of the Internal Medicine Group at the "Colentina" Clinical Hospital (1992-2006), the hospital where he began his career and ended more than forty years later.

The academic and medical career of Professor Ioan Matei was shaped in the "N. Gh. Lupu" Institute of Internal Medicine, one of the sanctuaries of Internal Medicine in Romania, under the guidance of great personalities in this specialty (Ioan Emil Bruckner and Simion Purice), who had an impact on his integrative medical thinking. In the high-level scientific and professional climate of the "Colentina" Hospital, Professor Ioan Matei dedicated himself to the study of systemic autoimmune diseases, in which he would later excel, becoming an authority in the field. He received a scholarship in Liège (Belgium) in 1971-1972, where he was trained in immunopathology and nephrology. This allowed him to become a Doctor of Philosophy in Medical Sciences in 1972, with the Ph.D. thesis entitled "The diagnostic value of the electrophoretic and immunoelectrophoretic study of proteinuria. Clinical, histological and electrophoretic correlations", under the supervision of Acad. Professor Dr. Ioan E. Bruckner. The scientific activity of Professor Ioan Matei, further developed to encompass research in nephrology and immunopathology and comprised over 200 scientific papers and awards afforded by the Romanian Society of Internal Medicine (2010) and by the Bucharest College of Physicians (2014). 
In 2004, Professor Ioan Matei was decorated by the President of Romania with the National Order "The Sanitary Merit", receiving the rank of officer.

His original scientific contributions encompass the study of the Balkan endemic nephropathy from Erghevița, Mehedinți county, the immunochemical diagnosis of proteinuria of different etiology, the use of the immunofluorescence technique in the differential diagnosis of nephropathy, as well as original diagnostic schemes in collagenosis and systemic vasculitis.

By virtue of his complex formation as a clinician, immunopathologist and nephrologist, Professor Ioan Matei managed to shed light on medical cases of high complexity, taking a keen interest in collagen vascular disease and other systemic afflictions with nephrological, gastrointestinal, hepatic and haematological involvement. He is a perfect example of modern internist and an eminent representative of the Romanian medical school that formed him as a doctor.

Likewise, Professor Ioan Matei assumed to guide the medical education of many generations of physicians at "Colentina" Hospital. His clinical trainees followed his footsteps and became excellent specialists in their fields. He is the author and co-author of the "Manual of Internal Medicine", vol. I and II, edited by I.E. Bruckner (1979); "Chronobiology and Medicine", vol. I and II, edited by D. Şteflea (1986); "Internal Medicine" edited by R. Păun (1987); "Nephrology", vol. II, edited by Al. Ciocâlteu (1997); "Internal Medicine", vol. I "Respiratory System Diseases" (2000) and vol. IV "Renal diseases" (2002), edited by L. Gherasim; "Manual of Nephrology" edited by N. Ursea (2001); "Antiphospholipid syndrome" edited by C. Tănăsescu (2005); "Nephrology", vol. II, edited by N. Ursea (2006).

His editorial activity is another commendable realm. Professor Ioan Matei was editor-in-chief of the "Romanian Journal of Internal Medicine" for ten years (1995-2005), editorial secretary of "Medicina Internă" (1966-1990) and member of the editorial board of the "Laborator Clinic" and "Infomedica" Romanian journals.

He was a dedicate man of exceptional sensitivity and modesty. An admirer of classical music, he would play the violin, accompanied by his sister on the piano. Later, his fondness for music would lead him to play the violin for many years in the Medical Symphony Orchestra in Bucharest, conducted by Dr. Ermil Nichifor.

He was a brilliant and dedicated physician, a distinguished Professor with a remarkable noble character and purity of thoughts, an example of honour, generosity and kindness towards other people. Those who have truly known and understood him will hold him in their memory forever.

The Editorial Board of the "Romanian Journal of Internal Medicine" 